\title{
Utilities Power Change: Engaging Commercial Customers in Workplace Charging
}

S. Lommele, National Renewable Energy Laboratory W. Dafoe, National Renewable Energy Laboratory June 2016
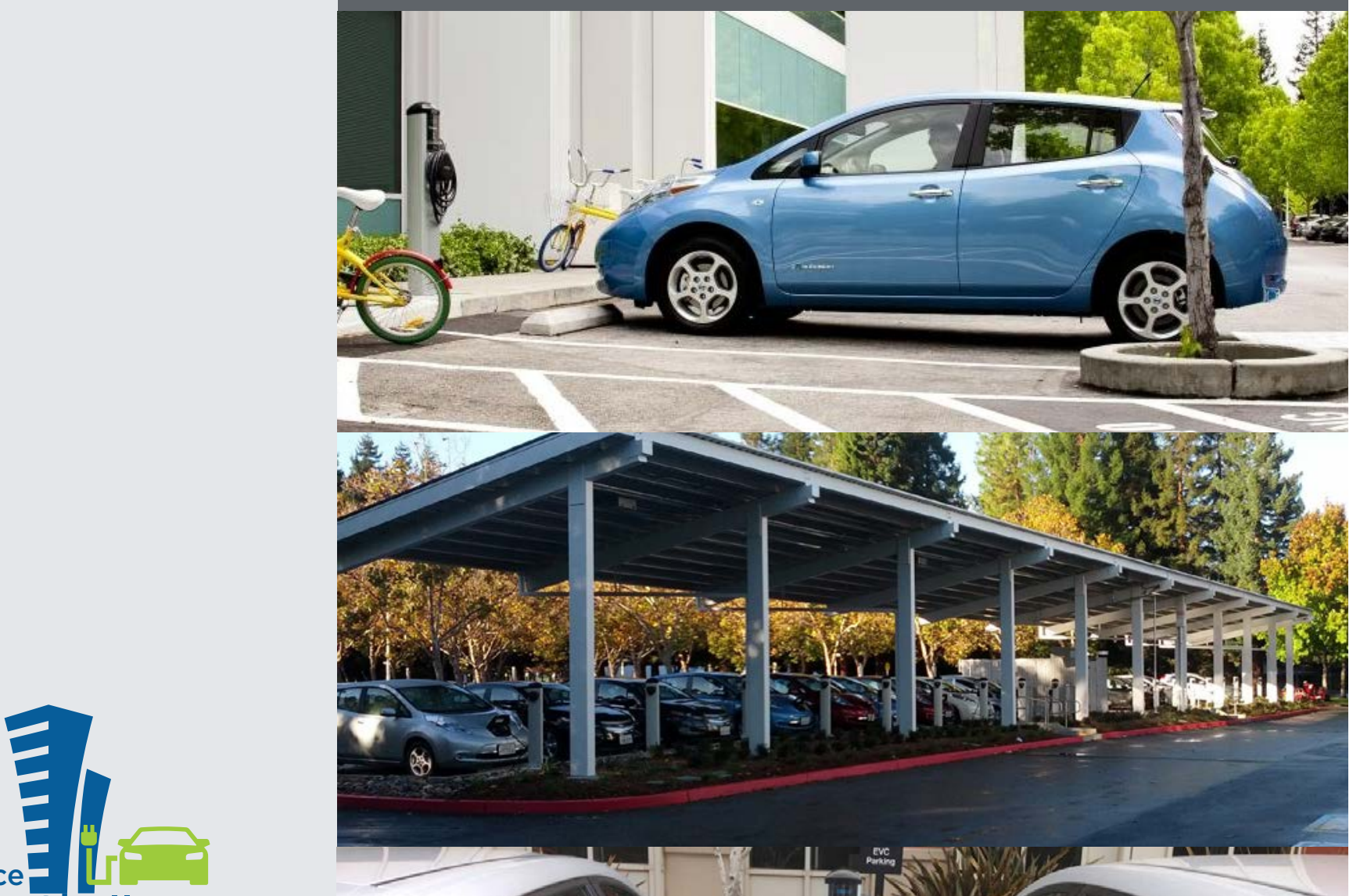
Workplace

ChargingChallenge

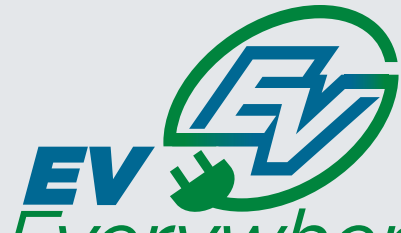

Everywhere

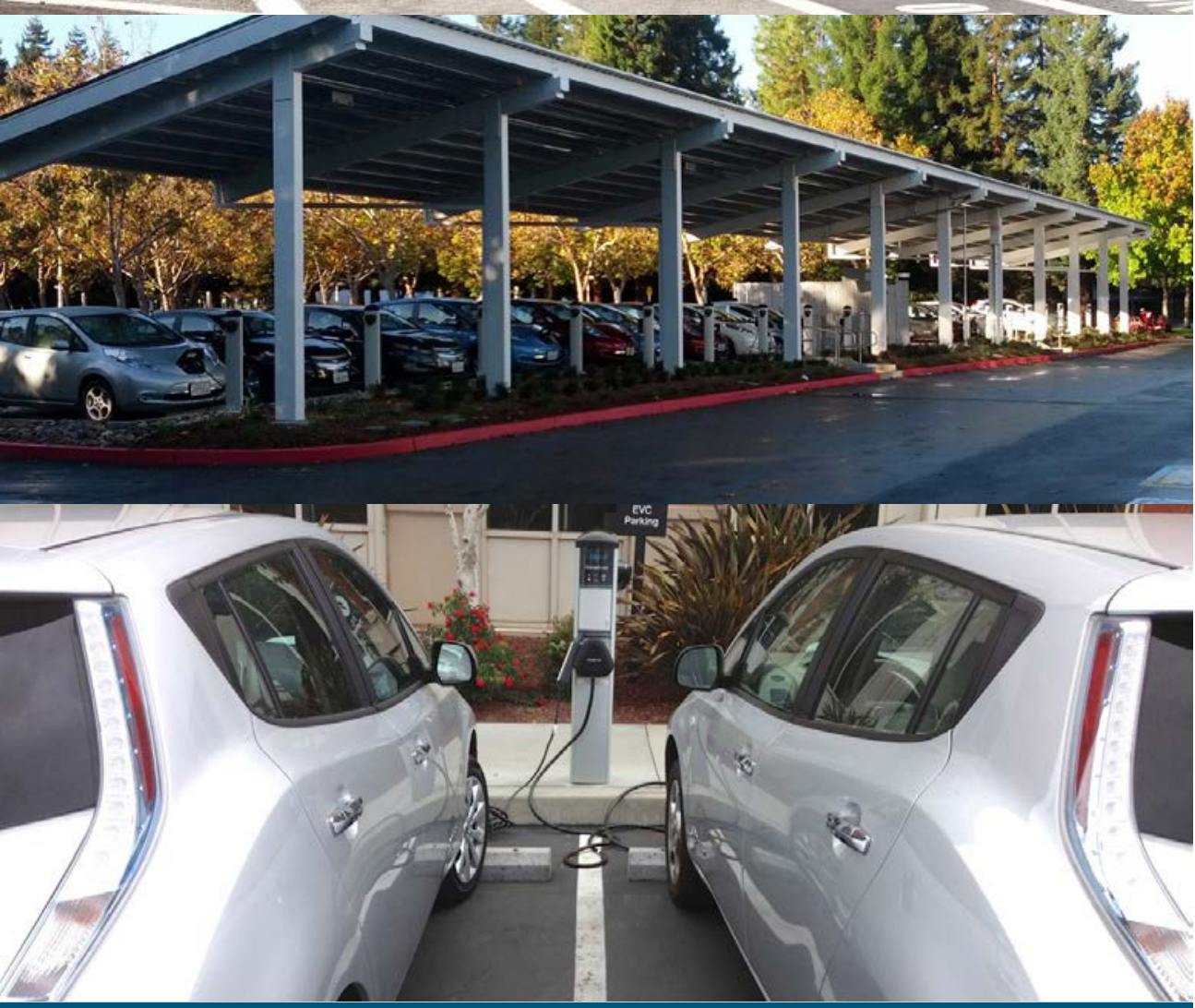




\section{NOTICE}

This report was prepared as an account of work sponsored by an agency of the United States government. Neither the United States government nor any agency thereof, nor any of their employees, makes any warranty, express or implied, or assumes any legal liability or responsibility for the accuracy, completeness, or usefulness of any information, apparatus, product, or process disclosed, or represents that its use would not infringe privately owned rights. Reference herein to any specific commercial product, process, or service by trade name, trademark, manufacturer, or otherwise does not necessarily constitute or imply its endorsement, recommendation, or favoring by the United States government or any agency thereof. The views and opinions of authors expressed herein do not necessarily state or reflect those of the United States government or any agency thereof.

This report is available at no cost from the National Renewable EnergyLaboratory (NREL) at www.nrel.gov/publications.

Available electronically at SciTech Connect http://www.osti.gov/scitech

Available for a processing fee to U.S. Department of Energy and its contractors, in paper, from:

U.S. Department of Energy

Office of Scientific and Technical Information

P.O. Box 62

Oak Ridge, TN 37831-0062

OSTI http://www.osti.gov

Phone: 865.576 .8401

Fax: 865.576.5728

Email: reports@osti.gov

Available for sale to the public, in paper, from:

U.S. Department of Commerce

National Technical Information Service

5301 Shawnee Road

Alexandria, VA 22312

NTIS http://www.ntis.gov

Phone: 800.553 .6847 or 703.605 .6000

Fax: 703.605.6900

Email: orders@ntis.gov 


\title{
Utilities Drive Change: Engaging Commercial Customers in Workplace Charging
}

\author{
Using electricity to power vehicles can help advance energy security and reduce emissions, and also presents a \\ new market opportunity for utilities looking to diversify and offer an added benefit to commercial customers. By \\ providing plug-in electric vehicle (PEV) charging stations for their employees, commercial customers can help \\ attract and retain a cutting-edge workforce. These employers also signal a commitment to sustainability and \\ demonstrate progressive leadership and a willingness to adopt advanced technology.
}

Utilities understand the distinctive challenges of their commercial customers, have access to technical information about electrical infrastructure, and have deep experience modeling and managing demand for electricity. As stewards of an electric grid that is available almost anywhere people park, utilities that support workplace charging are uniquely positioned to help their commercial customers be a part of the rapidly expanding network of charging infrastructure.

The U.S. Department of Energy (DOE) Workplace Charging Challenge is working with the Edison Electric Institute (EEI) to promote and support workplace charging deployment efforts across the country. Many utilities are promoting workplace charging both internally and externally, but two Challenge partner and EEI member utilities have taken significant steps toward changing the way their commercial customers' employees commute by enabling PEV owners to power up at work.

\section{Two utilities address workplace charging: PSE\&G launches pilot to explore potential market growth and Southern Company establishes proof of concept with internal program.}

\section{A New Market in New Jersey}

Public Service Electric and Gas Company (PSE\&G) is New Jersey's oldest and largest investor-owned utility. The company serves 1.8 million gas customers and 2.2 million electric customers. The PSE \&G service area is densely populated with a significant number of large employment centers, but the area experiences limited new growth. While this makes for a stable customer base, it poses little opportunity for new electricity markets. PSE\&G launched a workplace charging pilot program to explore how it might be a market growth opportunity and help the company prepare for possible future growth in the demand for PEV charging.

\section{From the Inside Out in Georgia}

Atlanta-based Southern Company serves 4.4 million customers in a 120,000-square-mile territory and owns electric utilities in four southern states including Alabama, Florida, Georgia, and Mississippi. Since the early 1990s, Southern Company has been part of the research, development, and marketing of PEV transportation and infrastructure, beginning with the deployment of the General Motors EV1 and the Toyota RAV4 PEVs. More recently, the utility has supported the growing PEV market with its workplace charging program; first with an internal program, then with a new offering for its customers.

\section{Understanding the Market}

Both PSE\&G and Southern Company unit Georgia Power recognized the possibilities of workplace charging, but still they wondered: "If we build it, will they come?" This is an important question for any utility considering a workplace charging program for its commercial customers. Fortunately, the unique experiences of each utility provide a roadmap for exploring employee and customer interest in PEVs, along with the prospects of charging at work. 


\section{Data drives customer engagement at PSE\&G while Southern Company unit Georgia Power} taps into lessons learned from internal customers.

\section{A Pilot Approach}

Faced with limited population growth, PSE\&G looked to workplace charging as a way to complement its other infrastructure and service enhancements, prepare for the future, and grow demand with its current customers. The utility was also interested in understanding how the growth of PEVs might impact its transmission and distribution system. PSE\&G's workplace charging pilot program was the result of a strategy to understand, prepare for, and develop a new market for electricity.

As a first step, the utility conducted research to understand the opportunities for and barriers to PEVs in its service area. PSE\&G developed a program for employees to test the concept of workplace charging. Individual employees committed to the concept by purchasing or leasing a PEV. In return, the employees enjoy designated parking with access to a vehicle charger at the utility's urban headquarters. The initial program, with 113 chargers, was so quickly adopted that PSE\&G recently added an additional 10 spaces with chargers.

The employee program helped PSE\&G understand that the dense population and large employment centers in its service area made it an ideal market for PEVs. However, research conducted by the utility determined that the typical commute for residents in its territory was close to 30 miles. For most PEV drivers, this commute distance without a means to charge the vehicle during the day would pose range anxiety, a documented barrier to PEV deployment.

To combat this, PSE\&G determined that workplace charging could help commuters to get to work and return home confidently in a PEV. However, the utility still questioned how the availability of workplace charging might help achieve its goal to create a new market opportunity.

PSE\&G established a pilot program to address this uncertainty, as well as collect and analyze data about the electricity demand from workplace charging. The utility's goal is to complete the installation of 125 chargers at 25 workplaces throughout their electric territory by the end of 2016 and collect data for two years. PSE\&G will then use the data to build models, develop plans for expansion, and implement contingencies for workplace charging growth in the service area.

Already, PSE\&G is using the data to help them understand how to best engage with customers about workplace charging, such as understanding the costs and benefits of owning charging stations and determining how much assistance to provide customers.

\section{Internal Proving Ground}

Prior to promoting workplace charging with its commercial customers, Georgia Power initiated its own employee charging program as part of its partnership in the U.S. Department of Energy's 2009 EV Project. Georgia Power received a project award because of the proven experience of its electric transportation group with PEVs and electric vehicle charging, making the utility well positioned to be a workplace charging expert. Initially, Georgia Power used the award to establish an in-house workplace charging program with 10 charging stations. The program was designed to help them gauge internal interest and understand how the availability of workplace charging might drive employees to purchase PEVs.

On Earth Day in 2010, Georgia Power partnered with Nissan for a ride-and-drive event at their corporate offices in Atlanta, Georgia, to help employees better understand PEVs, ask specific questions, and see how workplace charging could help them transition to a PEV. The event featured the commercially available Nissan Leaf and helped jump start the utility's own workplace charging program by demonstrating to employees that PEVs were a viable way to get to commute to work. The event was a game changer and employees swiftly began purchasing PEVs. The opportunity also showed employees that they could drive a PEV to work, charge at the office, and return home with confidence at the end of the day. 
As of November of 2015, Georgia Power had more than 350 employees with PEVs.

Building on its success with the ride-and-drive, Georgia Power now hosts an annual event with multiple manufacturers providing various PEV models available for test drives. The utility has also expanded free charging at its worksites to include more than 85 Level 2 chargers, 25 Level 1 chargers, and two direct-current (DC) fast chargers.

With the proven success of its internal program, Georgia Power was eager to share its knowledge and experience to help its customers establish workplace charging. Based on an internal employee survey, the utility found that workplace charging was a necessity for most people choosing to commute to work in a PEV (Figure 1).

Georgia Power used that information to develop and launch a two-year pilot of five outreachand incentive-based programs designed to help its customers also implement workplace charging.

\section{Connecting with Customers}

It is important to stay on target when starting small. PSE\&G launched its workplace charging efforts with a limited reach. For this reason, it was a high priority to focus outreach and engagement efforts to those customers most prepared and most likely to move forward with charging station installations.

Georgia Power, on the other hand, had proven experience with its internal workplace charging program and a long history of supporting PEVs. Accordingly, the utility cast a broader net when it began looking to connect with any customer interested in learning more about workplace charging.

\section{Georgia Power Electric Vehicle}

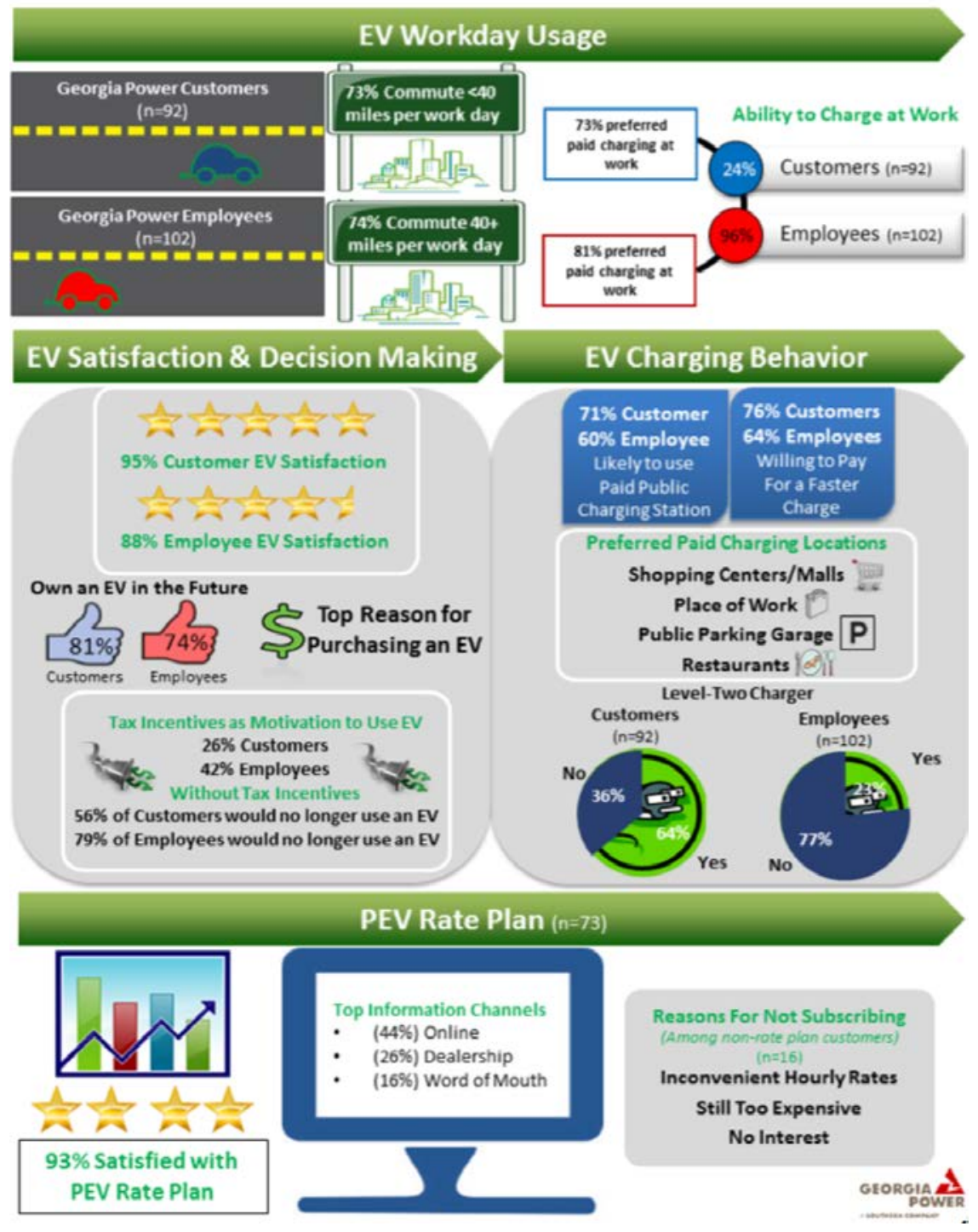

Figure 1. Infographic showing the number of respondents ( $\mathrm{n}$ ) and findings resulting from a survey about workplace charging and Georgia Power's PEV rate plan ( $\boldsymbol{w} w \boldsymbol{w}$. georgiapower.com/about-energy/electric-vehicles/what-rate-plan-is-best-foryou.cshtml). Infographic by Georgia Power

\section{PSE\&G targets early adopters with existing knowledge and experience; Georgia Power}

launches outreach campaign and incentives to educate and win new customers. 


\section{Sustainability as a Standard}

When PSE\&G began its search for potential clientele, the utility looked for customers with sustainability targets, suitable electrical infrastructure, and a demonstrated interest in workplace charging. Many of their customers had previously investigated installing charging stations and determined workplace charging would be a benefit they could provide to their employees. Additionally, many of their customers agreed that a workplace charging program was an easy expansion of their existing sustainability and marketing efforts.

The utility also looked for customers who had existing electrical infrastructure that could accommodate charging stations; PSE\&G did not want to dedicate resources to customers who would require upgraded service or transformers. Finally, the utility asked customers to conduct an informal survey before the process began to show that they had at least five employees interested in utilizing the charging stations.

Once PSE\&G identified a candidate, it found that it was best to determine early in the process how much each customer knew about PEVs and charging stations so the first meeting could build on existing knowledge.

The utility also recognized the importance of early adopters, like colleges and universities. These organizations helped the utility establish proof of concept and sell workplace charging to hesitant customers. PSE\&G worked to engage certain customers, such as those in leased facilities or remote offices, to better understand the needs of their employees.

PSE\&G discovered that frequently many minor decisions had to be made before a commercial customer would make the final decision to move forward with workplace charging. Often, there were competing agendas that had to be overcome. The utility learned to expect concerns and was prepared to spend time addressing each issue. From the initial conversation to ordering the charging stations, the process usually lasted about eight months.

Once a company agreed to participate in the workplace charging pilot program, the installation process was straight forward with PSE\&G supplying the equipment and the customer installing the equipment at their site. If installation questions arose, PSE\&G deferred to an outside installer or electrician for guidance.

Interestingly, PSE\&G also found several situations, including a high-end residential customer, where parking spaces are leased to workers employed in an adjacent office building during the day, thus qualifying as workplace charging. The charging station also provides residential charging for building occupants during off-hours.

\section{Casting a Broader Net}

Based on an internal employee survey, Georgia Power understood that in the designated service area, workplace charging was a necessity for most people to commute to work in a PEV. The utility used that information to develop and launch a two-year pilot of five outreach- and incentive-based programs designed to help its commercial customers implement workplace charging. They quickly realized that "workplace" had a different meaning across audiences and instead chose to focus the program on "businesses," including multi-family property owners, commercial and industrial users, police departments, and apartment residential units.

The incentive-based program provides a $\$ 500$ rebate for every alternating current Level 2 charger. A dual-port charger with a dedicated circuit is eligible for a $\$ 1,000$ rebate. Through November of 2015, Georgia Power awarded 495 rebates. Nissan has also matched 221 of those rebates, further helping to reduce the cost to commercial customers. Georgia Power's goal is to have 1,600 business charging sites established during the two-year pilot program.

In parallel to its rebate programs, the utility launched both internal education and external outreach programs. Their internal education program worked to ensure key account managers had a thorough understanding of PEVs and charging stations. Georgia Power used a variety of tactics to educate its sales force, including "lunch and learn" events, training programs, and ride-and-drives. These tactics, along with supporting outreach collateral, gave account managers the information and knowledge they needed to identify potential customers and confidently engage with them about the costs and benefits of installing charging at their businesses.

For its external outreach effort, Georgia Power launched a successful media campaign that included radio spots, digital and social media, and billboards to educate customers about PEVs and charging stations. This effort proved 
to have significant reach and impact. In addition, the utility held an annual energy forum for their largest commercial customers to complement other internal and external efforts and to help Georgia Power address the specific needs of those customers.

\section{Deploying Workplace Charging}

For both PSE\&G and Georgia Power, selling the customer on the concept of workplace charging represents the bulk of each programs' effort. The two utilities determined that the actual site assessment, installation, and ongoing maintenance were better left to independent contractors. Despite this, both PSE\&G and Georgia Power felt it was the utilities' responsibility to make sure there was a smooth transition and that their commercial customers were well positioned for success (see Table 1 for a summary of each program).

\section{Table 1. Summary of Utility Workplace Charging Pilots}

\begin{tabular}{|l|l|l|}
\hline & PSE\&G & Georgia Power \\
\hline Program Type & Pilot program & Rebate incentive \\
\hline Program Description & $\begin{array}{l}\text { Utility provides and owns charging } \\
\text { equipment; customer pays for } \\
\text { installation and electricity use }\end{array}$ & $\begin{array}{l}\$ 500 \text { rebate for each Level-2 charger, or } \\
\$ 1,000 \text { for a dual-port charger }\end{array}$ \\
\hline Charging Equipment Type & $\begin{array}{l}\text { Liberty Access Technologies Hydra } \\
\text { Controller }\end{array}$ & $\begin{array}{l}\text { Selected by customer; Georgia Power } \\
\text { shares list of providers that meet } \\
\text { standards }\end{array}$ \\
\hline Eligibility & $\begin{array}{l}\text { Limited program; customers } \\
\text { selected based on interest and site } \\
\text { characteristics }\end{array}$ & $\begin{array}{l}\text { Open to all customers based on } \\
\text { application }\end{array}$ \\
\hline Scale & $\begin{array}{l}\text { Target: } 125 \text { chargers at 25 sites by } \\
\text { end of } 2016\end{array}$ & $\begin{array}{l}\text { Target: 1,600 business charging sites } \\
\text { established during two-year program }\end{array}$ \\
\hline Additional information & $\begin{array}{l}\text { Contact } \\
\text { EVworkplacecharging@pseg.com }\end{array}$ & $\begin{array}{l}\text { See details at } \\
\text { georgiapower.com/EV }\end{array}$ \\
\hline
\end{tabular}

\section{Setting customers up for success: PSE\&G offers free charging stations and streamlined billing while Georgia Power provides rebates and offers recommendations on local service providers.}

Through the PSE\&G pilot program, each of the approximately 25 worksites pays for installation while the utility provides the charging station. PSE\&G identified Liberty Access Technologies' Hydra Controller, an application used to manage electric car needs, to supply smart charging capability. As an added benefit to PSE\&G, the system enables load shedding for demand response events. The Hydra system uses a processor and modem to collect and post data, sans personally identifiable information, to a secure website. Individual employers can determine whether employees are billed, or otherwise pay for charging time and energy use. If an employer decides to charge a fee, the Hydra system allows individual users to pay for charging through an established account similar to that of E-ZPass - the same system used to collect tolls on highways.

Additionally, the Hydra system can actively manage charging to multiple vehicles, communicating with owners of vehicles in queue to charge. This was important because the single biggest issue PSE\&G encountered was that their 
customers did not want to manage employee parking. Therefore, the pilot had to add workplace charging capability without adding the additional responsibility of managing parking.

PSE\&G's experience is that customers often establish websites, such as SharePoint, to foster communication between owners of PEVs, where they can share their experiences and best practices.

\section{Leaving Customers in Good Hands}

As the number of workplace charging installations increased, Georgia Power had to determine the appropriate services and expertise to provide to its customers. This was a balancing act focused on sharing Georgia Power's expertise and providing customers with the information needed to make good decisions, all while connecting customers with providers best equipped to meet the unique needs of each company and site.

From site assessments and charging station selection, to installations and ongoing maintenance, Georgia Power wanted to ensure the long-term success of its customers' workplace charging infrastructure. To help, Georgia Power issued a request for information (RFI) for local vendors and installers. From the submittals, they identified who could best manage the relationship with their customers. While they did not recommend specific providers, Georgia Power did evaluate each provider's capabilities against a set of standards and shared the list of companies who met the standards with customers.

Georgia Power also developed a program for new construction that provided a rebate for charging stations established during construction. Businesses are eligible for the $\$ 10,000$ rebate if they install five charging stations and establish the infrastructure to add another five chargers in the future.

\section{Gauging Impact}

PSE\&G and Georgia Power have gained significant insight from their investments in workplace charging. While it's likely that the availability of workplace charging has encouraged more commuters to make the switch to PEVs, both utilities continue to collect data and evaluate the impact to their customers, as well as their transmission and distribution systems.

\section{Incoming data and customer feedback will help determine next steps for each utility.}

\section{Waiting on a Data Download}

PSE\&G will judge the success of its workplace charging pilot on the data they collect. The models they create from that data will define how they proceed with promoting workplace charging among commercial customers. From a customer standpoint, the pilot has been an immediate success. PSE\&G has had several customers embrace workplace charging, which is encouraging more of its customers to investigate opportunities to install charging stations.

\section{Bolstered by State Incentives}

The initial success of the Georgia Power workplace charging program was bolstered by a Georgia tax credit for individuals who purchased or leased a new zero-emission vehicle. The tax credit was equal to $20 \%$ of the vehicle's cost, up to $\$ 5,000$. Low-speed vehicles did not qualify. The tax credit, combined with home charging and workplace charging, created an ideal market for the rapid adoption of PEVs. While the tax credit expired in July 2015, the early success of Georgia Power's workplace charging program has set the stage for continued growth of PEVs and charging stations among its customers.

\section{Attaining Success}

Thanks to a well-formulated strategy and a clear course of action, both utilities have seen success with their workplace charging programs. Georgia Power established its full-fledged program after an extremely popular ride-anddrive event spurred employee interest; this motivated the utility to hold similar events to achieve buy-in amongst its customers. Georgia Power's robust media campaign, coupled with its incentives, has also solidified its success. 
Similarly, PSE\&G's workplace charging program pilot was the answer to the utility's need to find new growth in a mature market. The pilot program is enabling the utility to collect data that will help it continue to analyze how workplace charging impacts the grid, and better understand how to assist customers in establishing their own workplace charging programs. 


\section{U.S. Department of Energy's Workplace Charging Challenge}

EV Everywhere is a Clean Energy Grand Challenge to enable plugin electric vehicles (PEVs) that are as affordable and convenient for the American family as gasoline-powered vehicles by 2022. To help accomplish this goal, the Workplace Charging Challenge encourages America's employers in all sectors of the economy to provide PEV charging access at their worksites.

The Workplace Charging Challenge provides resources, tools, and technical assistance to implement and manage workplace charging programs, and Challenge partners are nationally recognized for their sustainability efforts. For more information on workplace charging or becoming a partner, contact the Challenge at workplacecharging@ee.doe.gov. For more information on EV Everywhere, contact EV-Everywhere@ee.doe.gov.

\section{EV Everywhere Utility Partnership}

The U.S. Department of Energy (DOE) and Edison Electric Institute (EEI) launched the EV Everywhere Utility Partnership (EV Everywhere UP) in June 2015 to break down remaining barriers to widespread plug-in electric vehicle deployment. Through this partnership, DOE and EEI will work to advance the economic, environmental, and national security benefits of using electricity as a transportation fuel.

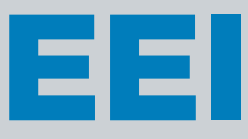

Edison Electric INSTITUTE 